\title{
Democratic Perception and Attitudes of Pre-Service Music Teachers in Turkey
}

\author{
Hatice Onuray Eğilmez ${ }^{1}$, Özgür Eğilmez ${ }^{2}$, Doruk Engür ${ }^{3}$ \\ ${ }^{1,3}$ Department of Music Education, Mehmet Akif Ersoy University, Turkey \\ ${ }^{2}$ Department of Music Education, Uludağ University, Turkey
}

\begin{tabular}{l}
\hline Article Info \\
\hline Article history: \\
Received May 14, 2018 \\
Revised May 27, 2018 \\
Accepted May 29, 2018 \\
\hline
\end{tabular}

\section{Keyword:}

Democratic attitudes Democratic perception Music teacher training Pre-service music teachers

\begin{abstract}
Democracy, a lifestyle as much as it is a form of government, begins to be learned in the family. The youth observe and acquire the democratic attitudes of their parents. The task of passing it on to the new generations and helping them acquire democratic values is the mission of schools, namely teachers. It is a commonly known fact that developmental level of countries shows parallelism with the democratic attitudes of individuals. It is important to understand the democratic perceptions and attitudes of teachers who are responsible for positioning democratic structure and thus raising the democratic level of countries. For this reason, the research aims to examine the democratic perceptions and attitudes of music teacher candidates in terms of some variables. Data collected using the democratic attitude scale was analyzed using t-test, Kruskal-Wallis H test, and Spearman's correlation coefficient. Results showed that attitude scores did not change according to gender, level of parents' education or the year students were in. Scale scores were negatively correlated with the amount of parents' income. There was no correlation between the students' GPAs and the scale scores. Music teaching requires a democratic environment intrinsically; therefore, the democratic perceptions and attitudes of the music teacher candidates who will carry out the music lessons in which they should maintain the democratic environment must be determined. As aforementioned notions suggest, this study is of the essence since the results will shed light on the academic staff in the institutions that train music teachers.
\end{abstract}

Copyright (C) 2018 Institute of Advanced Engineering and Science. All rights reserved.

\author{
Corresponding Author: \\ Hatice Onuray Eğilmez, \\ Department of Music Education, \\ Uludağ University, \\ Gorukle Campus, Nilufer-Bursa, 16059, Turkey. \\ Email: haticeegilmez@gmail.com
}

\section{INTRODUCTION}

It is known that developmental level of countries shows parallelism with the democratic attitudes of individuals. According to Gomleksiz [1], democracy is "a form of lifestyle and government based on human rights and freedoms in which majority has right to establish a policy, and minority has right to participate in and criticize". However, the sustainability of democracy can only be ensured in societies composed of individuals who accept democracy as a behavioral pattern and can bring democratic principles to their lives. Family and school are two important institutions in the development and socialization of individuals. Democracy, a lifestyle as much as it is a form of government, begins to be learned in the family by the democratic attitudes of parents. The task of passing it on to the new generations and helping them acquire democratic values is the mission of schools, namely teachers. If it is desired to raise individuals who believe in and live democracy, it is necessary that their educational environment especially their classroom is 
governed democratically and they experience democracy in the classroom [2]. Davies as cited by Karahan et al [3] also associates the development of democratic life culture to the democratic educational systems.

Dewey who is an important representative of libertarian tradition, whose origins are based on values of enlightenment, and dedicates his life and thoughts to democratic and educational issues prepared a report after his visit to Turkey during the years of the foundation of the Republic of Turkey, and it is thought that this report has been influential in the development of the Turkish National Education system. According to Dewey as cited by Gutek, democracy and education are hand in hand. Only a democratic education can create a democratic society. School should be a miniature society. Children can only get the basic principles of a democratic lifestyle in such a school [4].

Democracy Education and School Councils Project was put into practice in Turkey in 2004 and students were tried to be grown with democratic awareness from early ages and to gain the values such as voting, critical thinking, solidarity, reconciliation, participation, public opinion formation and democratic leadership adoption by practice [5].

In the new draft music lesson curriculum, which is planned to be implemented in 2017 and emphasized as the most important basic element constituting an education system, it is emphasized that the skills gained through education process contribute to the improvement of the living standards of the individuals and to the countries' global competition capacities and their democratic development [6].

Throughout history, democracy in Turkey has occasionally been interrupted due to various coups. This fact shows us that teachers need to be more sensitive in the name of democracy in order for democratic bases in our country to be solid, permanent and sustainable. According to Tuncel and Balci [7], teachers need to know the basic values of democracy and transform these values into behavior in their own life. Within this context, it is thought that it is important to understand the attitudes and perspectives of the teachers who are responsible for setting the democratic structure and thus raising the democratic level of the countries.

In the literature, there are studies conducted in Turkey on democratic attitudes of Turkish preservice teachers [8-17]. However, researches on the democratic perceptions and attitudes of music teachers are limited in our country. For this reason, in the study, the democratic perceptions and attitudes of the preservice music teachers, who will conduct music lessons that require a democratic environment inherently, are examined in terms of some variables.

In the research, it is aimed to examine the democratic perceptions and attitudes of the pre-service music teachers studying in Turkey in terms of some variables. The results related to democratic perceptions and attitudes of the pre-service music teachers who will conduct music lessons that require a democratic environment inherently will shed light on the academic staff in institutions that train music teachers, and this makes the research important. Furthermore, there is no study on democratic perceptions and attitudes of the pre-service music teachers in Turkey, and that increases the importance of the study.

\section{RESEARCH METHOD}

Correlational research model was used in the study. In this model, the aim is to estimate the level of relationship between two or more variables statistically and predict the possible results [18]. In this study, the relation between democratic perceptions and attitudes of the pre-service music teachers was examined in terms of variables such as gender, class level, grade point average (GPA), and parents' level of income, level of education, employment status and occupations.

The research population consisted of students studying at department of music education in Turkey. As a sample, 122 students ( 87 female, 35 male) studying at department of music education at 10 different universities were included in the research. Students mean age was $22.22(\mathrm{SD}=3.03)$. Twenty-six of the students were first-year students, 20 were second-year students, 32 were third-year students and 44 were fourth-year students.

In the research, a scale developed by Tutkun and Genc [17] to determine the democratic perceptions and attitudes of the pre-service teachers was used. In addition to the scale, a personal information form prepared by the researchers for the pre-service teachers was used in order to collect data. The scale consists of 36 items, 11 for the personal dimension, 11 for the educational dimension and 14 for the occupational dimension. 11 items at the personal level were about the pre-service teacher's being "open-minded, selfcritical, collaborative, sensitive and tolerant $\neg$ ", and if they "respects individual rights, believes in justice and equality and develops changing, progressing and problem solving strategies"; 11 items on the educational level to measure if the pre-service teacher "searches, analyzes and synthesizes, works with people with different opinions, shows respect to the people from different nation, religion, race and gender, and expresses himself/herself in class"; the 14 items at the occupational level to measure the situations where pre-service teacher "cooperates with colleagues, becomes fair and open to students, respects the rights of students, questions teaching skills and knowledge, uses different techniques, methods and activities while teaching, creates positive classroom atmosphere and classroom management, and gives feedback to the students". The 
reliability of the 5-point Likert type scale was calculated as 0.725 for personal dimension, 0.811 for educational dimension, and 0.897 for occupational dimension. In the present study, these coefficients were determined as $0.941,0.953,0.980$, respectively.

Before data analysis, parametric test assumptions were checked and it was determined to use t-test to analyze the scores in terms of gender, the Kruskal-Wallis $\mathrm{H}$ test to analyze the scores in terms of the class level of the pre-service teachers and parents' occupations, one-way ANOVA to analyze the scores in terms of parents' level of education and Mann-Whitney U test to analyze the scores in terms of parents' employment status. Spearman's correlation coefficient was calculated to determine correlations between attitude, income, and GPA variables.

\section{RESULTS AND ANALYSIS}

In order to determine the effect of gender on attitude scores, t-tests were employed. Test statistics are given in Table 1.

In Table 1, it is seen that female pre-service music teachers have a higher score in general and sub dimensions of democratic perception and attitude than males, but this difference is not statistically significant $(\mathrm{p}>.05)$

Table 1. T-Test Table Showing the Democratic Perception and Attitude Scores Differences of Preservice Music Teachers in terms of Gender

\begin{tabular}{|c|c|c|c|c|c|c|c|}
\hline Dimension & Gender & $N$ & $M$ & $S D$ & $t$ & $d f$ & $p$ \\
\hline \multirow[t]{2}{*}{ General } & Female & 87 & 4.40 & 0.72 & \multirow{2}{*}{0.79} & \multirow{2}{*}{120} & \multirow{2}{*}{.429} \\
\hline & Male & 35 & 4.28 & 0.72 & & & \\
\hline \multirow{2}{*}{ Personal } & Female & 87 & 4.31 & 0.74 & \multirow{2}{*}{0.34} & \multirow{2}{*}{120} & \multirow{2}{*}{.732} \\
\hline & Male & 35 & 4.26 & 0.71 & & & \\
\hline \multirow[t]{2}{*}{ Educational } & Female & 87 & 4.35 & 0.75 & \multirow[t]{2}{*}{0.78} & \multirow[t]{2}{*}{120} & \multirow[t]{2}{*}{.439} \\
\hline & Male & 35 & 4.24 & 0.74 & & & \\
\hline \multirow[t]{2}{*}{ Occupational } & Female & 87 & 4.51 & 0.76 & \multirow[t]{2}{*}{1.08} & \multirow[t]{2}{*}{120} & \multirow[t]{2}{*}{.281} \\
\hline & Male & 35 & 4.34 & 0.75 & & & \\
\hline
\end{tabular}

In order to determine the effect of class level on attitude scores, Kruskal-Wallis $\mathrm{H}$ tests were employed. Test statistics are given in Table 2.

In Table 2, it is seen that the general democratic perception and attitude scores of the pre-service music teachers do not change according to class level, $H(3)=1.32, p=.725$. It is also seen that the scores of each class level is quite close in the sub-dimensions and there is no significant difference between them. This can be interpreted as no significant change happens in students' democratic perceptions and attitudes during university education.

Table 2. Kruskal-Wallis Test Table Showing the Democratic Perception and Attitude Scores Differences of Pre-service Music Teachers in terms of Class Level

\begin{tabular}{|c|c|c|c|c|c|c|}
\hline & $N$ & $M$ & $S D$ & Mean Rank. & $H$ & $p$ \\
\hline \multicolumn{7}{|l|}{ Total } \\
\hline $1^{\text {st }}$ year student & 26 & 4.38 & 0.78 & 62.46 & & \\
\hline $2^{\text {nd }}$ year student & 20 & 4.56 & 0.35 & 68.78 & 1.32 & 0.725 \\
\hline $3^{\text {rd }}$ year student & 32 & 4.16 & 1.05 & 57.45 & & \\
\hline $4^{\text {th }}$ year student & 44 & 4.42 & 0.45 & 60.57 & & \\
\hline Personal & & & & & 1.80 & 0.614 \\
\hline $1^{\text {st }}$ year student & 26 & 4.24 & 0.82 & 60.40 & & \\
\hline $2^{\text {nd }}$ year student & 20 & 4.50 & 0.42 & 70.88 & & \\
\hline $3^{\text {rd }}$ year student & 32 & 4.11 & 1.03 & 57.92 & & \\
\hline $4^{\text {th }}$ year student & 44 & 4.37 & 0.45 & 60.49 & & \\
\hline Educational & & & & & 2.24 & 0.524 \\
\hline $1^{\text {st }}$ year student & 26 & 4.35 & 0.81 & 65.23 & & \\
\hline $2^{\text {nd }}$ year student & 20 & 4.50 & 0.43 & 68.60 & & \\
\hline $3^{\text {rd }}$ year student & 32 & 4.10 & 1.04 & 54.89 & & \\
\hline $4^{\text {th }}$ year student & 44 & 4.38 & 0.51 & 60.88 & & \\
\hline Occupational & & & & & 1.98 & 0.577 \\
\hline $1^{\text {st }}$ year student & 26 & 4.52 & 0.81 & 65.13 & & \\
\hline $2^{\text {nd }}$ year student & 20 & 4.66 & 0.37 & 69.33 & & \\
\hline $3^{\text {rd }}$ year student & 32 & 4.25 & 1.12 & 57.67 & & \\
\hline $4^{\text {th }}$ year student & 44 & 4.50 & 0.49 & 58.58 & & \\
\hline
\end{tabular}


In order to determine the relations among variables, Spearman's correlation coefficients were calculated. Test statistics are given in Table 3.

When Table 3 is examined, it is seen that general democratic perception and attitude scores of preservice music teachers are correlated with sub-dimension scores as expected. A weak negative correlation is detected between the general democratic perception and attitude score $(\mathrm{r}=.199, \mathrm{p}=.031)$. The income level is also negatively correlated with the occupational sub-dimension of the attitude $(r=.210, p=.023)$. It is determined that there is no significant difference according to the GPA variable

Table 3. Correlations of Democratic Perceptions and Attitudes of Pre-service Music Teachers with Income

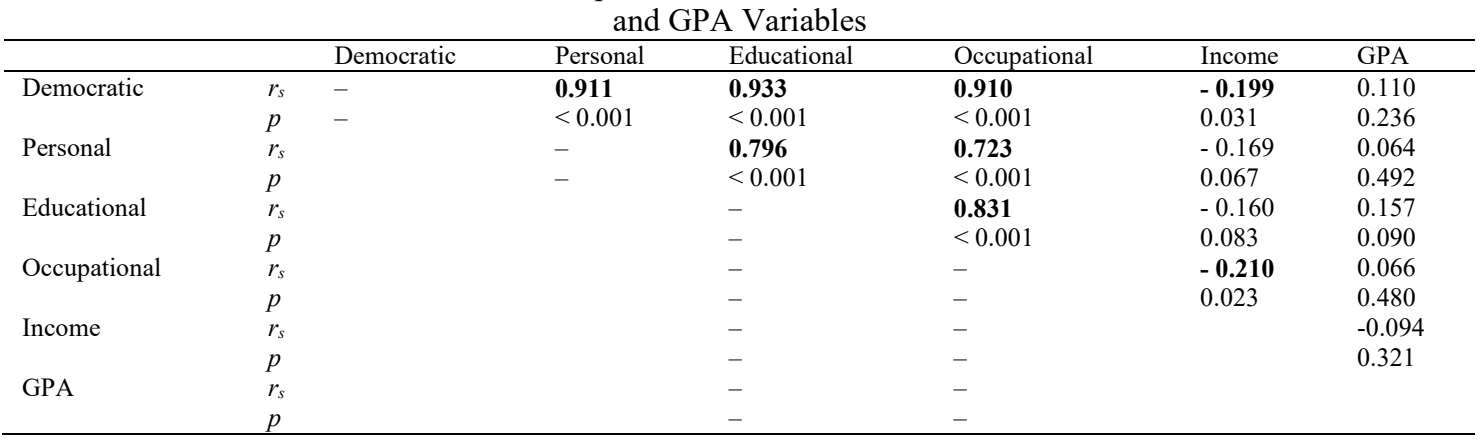

In order to determine the effect of parents' education level on attitude scores, One-way ANOVAs were employed. Test statistics are given in Table 4.

In Table 4, it is seen that mother's level of education does not have an effect on the democratic perceptions and attitudes of the pre-service music teachers, $F(2,119)=0.217, p>.05$ and the father's level of education also does not have any effect on the attitude, $F(2,119)=1.389, p=.25)$. It is understood that no sub-dimension is affected by the education level of the mother or father.

Table 4. ANOVA Test Showing the Democratic Perception and Attitude Scores Differences of Pre-service Music Teachers in terms of Parents' Level of Education

\begin{tabular}{|c|c|c|c|c|c|c|c|c|c|c|}
\hline & & $\begin{array}{c}\text { Level of } \\
\text { Education }\end{array}$ & $N$ & $M$ & $S D$ & $S S$ & $d f$ & $M S$ & $F$ & $p$ \\
\hline \multirow[t]{16}{*}{ Mother } & Democratic (General) & 1 & 45 & 4.37 & 0.83 & & & & & \\
\hline & & 2 & 43 & 4.37 & 0.62 & 0.000 & 2 & 0.000 & 0.217 & 1.0 \\
\hline & & 3 & 34 & 4.37 & 0.70 & & & & & \\
\hline & Residual & & & & & 62.804 & 119 & 0.528 & & \\
\hline & Democratic & 1 & 45 & 4.23 & 0.81 & & & & & \\
\hline & (Personal) & 2 & 43 & 4.33 & 0.63 & 0.121 & 2 & 0.061 & 0.114 & 0.89 \\
\hline & & 3 & 34 & 4.25 & 0.74 & & & & & \\
\hline & Residual & & & & & 63.623 & 119 & 0.535 & & \\
\hline & Democratic & 1 & 45 & 4.30 & 0.84 & & & & & \\
\hline & (Educational) & 2 & 43 & 4.32 & 0.66 & 0.044 & 2 & 0.022 & 0.039 & 0.96 \\
\hline & & 3 & 34 & 4.35 & 0.73 & & & & & \\
\hline & Residual & & & & & 66.633 & 119 & 0.560 & & \\
\hline & Democratic & 1 & 45 & 4.47 & 0.88 & & & & & \\
\hline & (Occupational) & 2 & 43 & 4.44 & 0.65 & 0.024 & 2 & 0.012 & 0.021 & 0.98 \\
\hline & & 3 & 34 & 4.47 & 0.74 & & & & & \\
\hline & Residual & & & & & 70.253 & 119 & 0.590 & & \\
\hline \multirow[t]{16}{*}{ Father } & Democratic & 1 & 35 & 4.22 & 1.07 & & & & & \\
\hline & (General) & 2 & 49 & 4.49 & 0.42 & 1.432 & 2 & 0.716 & 1.389 & 0.25 \\
\hline & & 3 & 38 & 4.35 & 0.62 & & & & & \\
\hline & Residual & & & & & 61.372 & 119 & 0.516 & & \\
\hline & Democratic (Personal) & 1 & 35 & 4.15 & 1.03 & & & & & \\
\hline & & 2 & 49 & 4.40 & 0.45 & 1.221 & 2 & 0.610 & 1.162 & 0.32 \\
\hline & & 3 & 38 & 4.30 & 0.67 & & & & & \\
\hline & Residual & & & & & 62.523 & 119 & 0.525 & & \\
\hline & Democratic & 1 & 35 & 4.17 & 1.07 & & & & & \\
\hline & (Educational) & 2 & 49 & 4.42 & 0.47 & 1.235 & 2 & 0.617 & 1.122 & 0.33 \\
\hline & & 3 & 38 & 4.33 & 0.66 & & & & & \\
\hline & Residual & & & & & 65.442 & 119 & 0.550 & & \\
\hline & Democratic & 1 & 35 & 4.32 & 1.12 & & & & & \\
\hline & (Occupational) & 2 & 49 & 4.61 & 0.46 & 1.922 & 2 & 0.961 & 1.673 & 0.19 \\
\hline & & 3 & 38 & 4.40 & 0.64 & & & & & \\
\hline & Residual & & & & & 68.356 & 119 & 0.574 & & \\
\hline
\end{tabular}


In order to determine the effect of parents' employment status on attitude scores, Mann-Whitney U tests were employed. Test statistics are given in Table 5.

In Table 5, it is seen that there is no significant difference between demographic perceptions and attitudes and pre-service music teachers' mothers' employment status $(U=1610.5, p=.71)$. Similarly, the fact that father is working or not does not significantly affect the democratic perceptions and attitudes of preservice music teachers $(U=1395.0, p=.56)$. It can be said that the sub-dimensions are not affected by the parents' employment status.

Table 5. Mann-Whitney U Test Table Showing the Pre-service Music Teachers' Democratic Perception and Attitude Scores Differences in terms of Parents' Employment Status

\begin{tabular}{|c|c|c|c|c|c|c|c|c|}
\hline & & & $N$ & $M$ & $S D$ & Mean Rank. & $U$ & $p$ \\
\hline \multirow[t]{8}{*}{ Mother } & \multirow[t]{2}{*}{ Democratic (General) } & Working & 42 & 4.40 & 0.68 & 63.15 & \multirow[t]{2}{*}{1610.5} & \multirow[t]{2}{*}{0.71} \\
\hline & & Not Working & 80 & 4.35 & 0.74 & 60.63 & & \\
\hline & \multirow[t]{2}{*}{ Democratic (Personal) } & Working & 42 & 4.35 & 0.71 & 65.62 & \multirow[t]{2}{*}{1507.0} & \multirow[t]{2}{*}{0.35} \\
\hline & & Not Working & 80 & 4.26 & 0.73 & 59.34 & & \\
\hline & \multirow[t]{2}{*}{ Democratic (Educational) } & Working & 42 & 4.36 & 0.71 & 63.87 & \multirow[t]{2}{*}{1580.5} & \multirow[t]{2}{*}{0.59} \\
\hline & & Not Working & 80 & 4.30 & 0.76 & 60.26 & & \\
\hline & \multirow[t]{2}{*}{ Democratic (Occupational) } & Working & 42 & 4.47 & 0.73 & 59.92 & \multirow[t]{2}{*}{1613.5} & \multirow[t]{2}{*}{0.72} \\
\hline & & Not Working & 80 & 4.46 & 0.78 & 62.33 & & \\
\hline \multirow[t]{8}{*}{ Father } & \multirow[t]{2}{*}{ Democratic (General) } & Working & 88 & 4.39 & 0.61 & 60.35 & \multirow[t]{2}{*}{1395.0} & \multirow[t]{2}{*}{0.56} \\
\hline & & Not Working & 34 & 4.30 & 0.95 & 64.47 & & \\
\hline & \multirow[t]{2}{*}{ Democratic (Personal) } & Working & 88 & 4.31 & 0.63 & 60.22 & \multirow[t]{2}{*}{1383.5} & \multirow[t]{2}{*}{0.52} \\
\hline & & Not Working & 34 & 4.26 & 0.94 & 64.81 & & \\
\hline & \multirow[t]{2}{*}{ Democratic (Educational) } & Working & 88 & 4.35 & 0.64 & 61.24 & \multirow[t]{2}{*}{1473.0} & \multirow[t]{2}{*}{0.89} \\
\hline & & Not Working & 34 & 4.24 & 0.96 & 62.18 & & \\
\hline & \multirow[t]{2}{*}{ Democratic (Occupational) } & Working & 88 & 4.50 & 0.65 & 60.86 & \multirow[t]{2}{*}{1439.5} & \multirow[t]{2}{*}{0.74} \\
\hline & & Not Working & 34 & 4.38 & 1.00 & 63.16 & & \\
\hline
\end{tabular}

In order to determine the effect of parents' professions on attitude scores, Kruskal-Wallis $\mathrm{H}$ tests were employed. Test statistics are given in Table 6.

As seen in Table 6, it is determined that there is no significant effect of the mother's profession on the democratic perceptions and attitudes of pre-service music teachers, $H(3)=3.93, p=.27$. Similarly, the father's profession has no significant effect on the democratic perception and attitude, $H(7)=8.95, p=.26$. It is also determined that there is no significant difference in the sub-dimensions, and that suggests that the parents' occupations have no significant influence on democratic perception and attitude. However, when the sample is taken into consideration only, it is seen that the attitudes of the health workers' children are slightly higher.

Table 6. Kruskal-Wallis Test Table Showing the Democratic Perception and Attitude Scores Differences of Pre-service Music Teachers in terms of Parents' Profession

\begin{tabular}{|c|c|c|c|c|c|c|c|}
\hline & & $N$ & $M$ & $S D$ & Mean Rank. & $H$ & $p$ \\
\hline \multirow[t]{20}{*}{ Mother } & Total & & & & & & \\
\hline & Education & 14 & 4.30 & 0.41 & 16.79 & & \\
\hline & Worker & 14 & 4.39 & 1.03 & 25.07 & 3.93 & 0,27 \\
\hline & Self-employment & 7 & 4.40 & 0.54 & 20.21 & & \\
\hline & Healthcare & 7 & 4.62 & 0.31 & 25.07 & & \\
\hline & Personal & & & & & & \\
\hline & Education & 14 & 4.27 & 0.53 & 17.32 & & \\
\hline & Worker & 14 & 4.32 & 1.03 & 23.61 & 2.71 & 0.44 \\
\hline & Self-employment & 7 & 4.49 & 3.81 & 21.93 & & \\
\hline & Healthcare & 7 & 4.54 & 0.77 & 25.21 & & \\
\hline & Educational & & & & & & \\
\hline & Education & 14 & 4.30 & 0.42 & 16.21 & & \\
\hline & Worker & 14 & 4.35 & 1.04 & 24.50 & 6.31 & 0.1 \\
\hline & Self-employment & 7 & 4.26 & 0.64 & 18.79 & & \\
\hline & Healthcare & 7 & 4.70 & 0.34 & 28.79 & & \\
\hline & Occupational & & & & & & \\
\hline & Education & 14 & 4.35 & 0.48 & 16.79 & & \\
\hline & Worker & 14 & 4.47 & 1.05 & 24.61 & 3.60 & 0.31 \\
\hline & Self-employment & 7 & 4.45 & 0.75 & 21.21 & & \\
\hline & Healthcare & 7 & 4.68 & 0.34 & 25.00 & & \\
\hline \multirow[t]{3}{*}{ Father } & Total & & & & & & \\
\hline & Education & 11 & 4.32 & 0.43 & 36,82 & 8.95 & 0.26 \\
\hline & Worker & 20 & 4.62 & 0.43 & 56,45 & & \\
\hline
\end{tabular}

IJERE Vol. 7, No. 2, June2018: $100-108$ 


\begin{tabular}{|c|c|c|c|c|c|c|}
\hline \multirow[b]{2}{*}{ Self-employment } & & \\
\hline & 27 & 4.31 & 0.76 & 41,63 & & \\
\hline Security & 7 & 4.17 & 1.17 & 46,79 & & \\
\hline Manager & 9 & 4.38 & 0.39 & 37,17 & & \\
\hline Healthcare & 3 & 4.75 & 0.18 & 61,17 & & \\
\hline Engineer & 5 & 4.27 & 0.37 & 32,70 & & \\
\hline Civil Servant & 6 & 4.45 & 0.35 & 41,50 & & \\
\hline \multicolumn{7}{|l|}{ rsonal } \\
\hline Education & 11 & 4.22 & 0.63 & 39,55 & \multirow{8}{*}{6.31} & \multirow{8}{*}{0.5} \\
\hline Worker & 20 & 4.54 & 0.47 & 54,65 & & \\
\hline Self-employment & 27 & 4.24 & 0.73 & 41,43 & & \\
\hline Security & 7 & 4.18 & 1.22 & 51,14 & & \\
\hline Manager & 9 & 4.23 & 0.35 & 34,83 & & \\
\hline Healthcare & 3 & 4.33 & 0.53 & 42,50 & & \\
\hline Engineer & 5 & 4.25 & 0.37 & 36,90 & & \\
\hline Civil Servant & 6 & 4.44 & 0.34 & 47,67 & & \\
\hline \multicolumn{7}{|l|}{ lucational } \\
\hline Education & 11 & 4.33 & 0.50 & 39,32 & \multirow{8}{*}{10.44} & \multirow{8}{*}{0.17} \\
\hline Worker & 20 & 4.60 & 0.48 & 56,45 & & \\
\hline Self-employment & 27 & 4.24 & 0.75 & 39,30 & & \\
\hline Security & 7 & 4.14 & 1.14 & 44,57 & & \\
\hline Manager & 9 & 4.32 & 0.52 & 39,67 & & \\
\hline Healthcare & 3 & 4.84 & 0.14 & 71,00 & & \\
\hline Engineer & 5 & 4.31 & 0.40 & 36,50 & & \\
\hline Civil Servant & 6 & 4.30 & 0.51 & 38,17 & & \\
\hline \multicolumn{7}{|l|}{ cupational } \\
\hline Education & 11 & 4.38 & 0.43 & 32,68 & \multirow{8}{*}{12.19} & \multirow{8}{*}{0.0} \\
\hline Worker & 20 & 4.71 & 0.41 & 53,48 & & \\
\hline Self-employment & 27 & 4.43 & 0.82 & 43,78 & & \\
\hline Security & 7 & 4.17 & 1.19 & 43,57 & & \\
\hline Manager & 9 & 4.54 & 0.44 & 42,00 & & \\
\hline Healthcare & 3 & 5.00 & 0.00 & 76,50 & & \\
\hline Engineer & 5 & 4.24 & 0.51 & 27,60 & & \\
\hline Civil Servant & 6 & 4.58 & 0.32 & 42,42 & & \\
\hline
\end{tabular}

\section{DISCUSSION}

It is determined that although it is not statistically significant, female pre-service music teachers have a higher score in general and sub-dimensions of democratic perception and attitude than male preservice music teachers. In the Turkish society, the male dominant society, statistics show that the rate of female literacy, university graduation, being in working and social life, and even the number of deputies in the parliament is far behind men [19]. The high level of democratic perceptions and attitudes of female preservice music teachers compared to male pre-service music teachers can be attributed to the fact that this situation has occurred as a reaction to gender discrimination. Similar results are obtained in the researches on the democratic attitudes of the pre-service teachers in various branches and it is found that the democratic attitudes of the female students are significantly more positive than male students [10,12,16,20-22]. However, Saracaloglu et al. [13], Elkatmis and Topbas [21] report that there is no statistically significant difference in the democratic attitudes of pre-service classroom teachers in terms of gender.

In the research, it is determined that the general democratic perception and attitude scores of the preservice music teachers do not change according to the class level. It is seen that the scores of the class levels are very close to each other and there is no significant difference in the sub-dimensions. This situation can be interpreted as no significant change happens in democratic perceptions and attitudes of the students during university education. The fact that pre-service music teachers have no activities for democratic attitude in the context of the lessons they have taken during their music teacher education in university may explain this. The results Tekin et al. [16], and Genç and Kalafat [21] obtained are parallel to our research results, but in his research, Bulut [23] points out that the fourth year pre-service teachers have the highest democratic attitude.

It has been determined that general democratic perception and attitude scores of the pre-service music teachers are correlated with sub-dimension scores. It is seen that there is no significant difference with the GPA variable, but the income level is correlated with the general democratic perception and attitude score at a weak level but negatively. It has been determined that the level of income negatively correlates with the occupational sub-dimension of the attitude. Similar results were obtained in Gomleksiz and Cetintas' [10] research. It is determined that there is a significant difference between the democratic attitude scores of the pre-service teachers in terms of the families' level of income variable and the democratic attitude scores of the pre-service teachers with middle and lower income families were significantly higher than the demographic attitude scores of the pre-service teachers with high income. However, another study on parental attitudes [24] indicates that there is no significant difference between the parents' democratic attitudes according to monthly income. It has been found put that there are other researches that cannot 
determine a significant difference between the level of income of the pre-service teachers' families and their democratic attitudes [22].

In the study, it has been determined that the educational status of the mother and father had no effect on the democratic perceptions and attitudes of the pre-service music teachers, and any sub-dimension was affected by the education level of the mother or father. Democratic education begins in the family. Despite this, the result obtained in the research is considered to be surprising. However, similar results have been obtained in the researches of Genc and Kalafat [21], Aydemir and Aksoy [20], Gomleksiz and Cetintas [10], Elkatmis and Topbas [22] on the democratic attitudes of pre-service teachers. In the study conducted by Gomleksiz and Cetintas [10], it is recorded as a striking finding that those whose mothers are university graduate have the lowest attitude score and those whose mothers are illiterate have the highest attitude score. However, in another study [24] conducted on the attitudes of the parents, it is found out that democratic attitude scores of undergraduate parents are significantly higher than the democratic attitude scores of the secondary school graduates. Contrary to this result, Saracoglu et al. [12] and Tekin et al. [16] state that the democratic attitude score increases significantly as mother and father's level of education increases.

It has been determined that the fact whether the mother or father is working or not does not create a meaningful difference in terms of the democratic perceptions and attitudes of the pre-service music teachers. It can be said that the sub-dimensions are also not affected by the parents' employment status. Although parents who do not work are thought to have more chances to spend time with their children, students who are studying at university are away from home and this causes the parents to be less influential on their democratic perceptions, so this may cause the employment status of the parents not to have an effect on democratic perceptions and attitudes. In a study conducted on attitudes of the parents [24], it is stated that democratic attitudes do not show significant difference according to the employment status of the parents.

It has been determined that the parents' professions have no significant effect on the democratic perceptions and attitudes of the pre-service music teachers. It has been also found out that there is no significant difference in the sub-dimensions and that suggests that the parental occupation has no significant influence on democratic perception and attitude. However, when the data in the sample are examined, it is seen that the health workers' children's democratic attitudes are slightly higher. However, in the research conducted by Aydemir and Aksoy [20], it is stated that there is a significant difference between the democratic attitudes of the students and the professions of their mothers. It is stated that the difference considered as significant professions is between self-employed group and housewives, teachers and retired group. In the same study, it has been found out that there is no significant difference between the democratic attitudes of pre-service teachers and the professions of their fathers. In his research, Bulut [23] concluded that the democratic attitudes of pre-service teachers are not related to their mothers' professions but to their fathers' professions. According to the democratic attitude scale average scores, Bulut [23] states that when the maternal profession is examined, pre-service teachers who indicate their mothers' profession as a teacher have the highest democratic attitude and when the paternal profession is examined, pre-service teachers who indicate their fathers' profession as a worker had the highest democratic attitude

\section{CONCLUSION AND SUGGESTIONS}

In the direction of the results obtained, no change has been observed in the democratic attitudes of the pre-service music teachers for 4 years during the university life. Within the scope of life-long education, informative meetings for democracy education to be given in music education departments for 4 years, courses or behaviors required for democratic life, elections, and such activities may raise awareness among pre-service teachers in this field. This may reflect positively on conducting future music teachers' music lessons, which require a democratic environment inherently.

The democratic attitude scores of male pre-service music teachers were found to be lower than female students', although it is not significant. At this point, organizing activities to increase the democratic attitudes of the male pre-service music teachers may provide positive contributions to the community life in the male dominant Turkish society.

Further research may be done to compare the democratic attitudes of the pre-service music teachers with the democratic attitudes of the pre-service teachers who are trained in other teaching areas, so that the level of democratic attitudes of the pre-service music teachers to other pre-service teachers can be determined. With different variables, the democratic attitudes of the pre-service music teachers can be examined from different angles. If a study that compare the democratic attitudes of the pre-service music teachers and the democratic attitudes of the music teachers working now, the implementation phase will also be propounded.

IJERE Vol. 7, No. 2, June2018 : $100-108$ 


\section{REFERENCES}

[1] Gömleksiz M. Demokratik bir sınıf ortamı açısından Hacettepe Üniversitesi Eğitim Fakültesi öğretim elemanlarının ve öğrencilerinin davranışlarının değerlendirilmesi [Master's thesis]. Hacettepe Üniversitesi Sosyal Bilimler Enstitüsü, 1988.

[2] Demirtaş H. Demokratik sınıf yönetimi ve üniversite öğrencilerinin öğretim elemanlarının sınıf içi tutum ve davranışlarına ilişkin görüşleri. In: XIII Ulusal Eğitim Bilimleri Kurultayı. Malatya: İnönü Üniversitesi, Eğitim Fakültesi; 16-19 July, 2004.

[3] Karahan TF, Sardoğan ME, Özkamalı E, Dicle AN. Ögretmen adaylarında demokratik tutum, nevrotik eğilimler ve kendini gerçekleştirme. HÜ Eğitim Fakültesi Dergisi [Internet]. 2006;(30):149-58. Available from: http://dergipark.gov.tr/download/article-file/87668

[4] Gutek GL. Eğitimin felsefi ve ideolojik temelleri. Trans N. Kale. Ankara: Ütopya Yayınevi; 2001.

[5] Sadık F, Sarı M. Çocuk ve demokrasi: İlköğretim öğrencilerinin demokrasi algılarının metaforlar aracıllğıyla incelenmesi. Uluslararas1 Cumhuriyet Eğitim Dergisi [Internet]. 2012;1(1):48-62. Available from: http://dergipark.gov.tr/download/article-file/48602

[6] Milli Eğitim Bakanlığı. Müzik dersi öğretim programı tanıtım sunusu [Internet]. 2017. Available from: http://tegm.meb.gov.tr/meb_iys_dosyalar/2017_06/09163315_MYzik_Dersi_YYretim_ProgramY_Genel_Sunum.p df

[7] Tuncel G, Balcı A. Demokratik toplumlarda öğretmen nitelikleri ve öğrencilere yansımaları. Marmara Coğrafya Dergisi [Internet]. 2015;[31):82-97. Available from: http://dergipark.gov.tr/download/article-file/3458

[8] Akbaşlı S, Yanpar Yelkenli T, Sünbül Ö. Öğretmen adayı demokratik eğilim ölçeği geliştirme çalışması. Uluslararası Avrasya Sosyal Bilimler Dergisi. 2010;1(1):94-108.

[9] Genç SZ, Kalafat T. Öğretmen adaylarının demokratik tutumları ile problem çözme becerilerinin çeşitli değişkenler açısından incelenmesi. Pamukkale Üniversitesi Eğitim Fakültesi Dergisi [Internet]. 2007;2(22):10-22. Available from: http://dergipark.gov.tr/download/article-file/114708

[10] Gömleksiz MN, Çetintaş S. Öğretmen adaylarının demokratik tutumları (Fırat, Dicle, 7 Aralık, Cumhuriyet ve Erzincan üniversiteleri örneği). Dicle Üniversitesi Ziya Gökalp Eğitim Fakültesi Derg [Internet]. 2011;(17):1-14. Available from: http://zgefdergi.com/Makaleler/315722388_17_01_Gomleksiz-Cetintas.pdf

[11] Karatekin K, Merey Z, Kuş Z. Öğretmen adayları ve öğretmenlerin demokratik tutumlarının çeşitli değişkenler açısından incelenmesi. Kastamonu Eğitim Dergisi [Internet]. 2013;21(2):561-74. Available from: http://www.kefdergi.com/pdf/21_2/21_2_11.pdf

[12] [Saracaloğlu AS, Evin I, Varol SR. İzmir ilinde çeşitli kurumlarda görev yapan öğretmenler ile öğretmen adaylarının demokratik tutumları üzerine karşılaştırmalı bir araştırma. Kuram ve Uygulamada Eğitim Bilim. 2004;4(2):335-64.

[13] Saracaloğlu AS, Uça S, Başara Baydilek N, Coşkun N. Öğretmen Adaylarının Demokratik Tutumları ile Değer Algılarının. Adnan Menderes Üniversitesi Eğitim Fakültesi Eğitim Bilimleri Dergisi [Internet]. 2013;4(1):45-59. Available from: http://dergipark.gov.tr/download/article-file/399507

[14] Sarı M, Sadık F. Öğretmen adaylarının demokrasi algıları (Çukurova Üniversitesi Örneği). Uluslararası Eğitim Programları ve Öğretim Çalışmaları Dergisi [Internet]. 2011;1(2):67-82. Available from: https://www.pegem.net/dosyalar/dokuman/131598-2012041217290-6.pdf

[15] Altunay Şam E, Çaypınar İ, Alimcan D. Öğretmen Adaylarının Demokratik Tutumları ve Şiddete Karşı Tutumları Arasındaki İlişki (Amasya Üniversitesi Örneği). İstanbul Eğitimde Yenilikçilik Dergisi. 2016;2(2):31-53.

[16] [Tekin M, Yıldız M, Lök S, Taşğın Ö. Beden Eğitimi Ve Spor Yüksekokulunda öğrenim gören öğretmen adaylarının çeşitli değişkenlere göre demokratik tutum düzeylerinin incelenmesi. Niğde Üniversitesi Beden Eğitimi ve Spor Bilimleri Dergisi. 2009;3(3):204-212.

[17] Tutkun T, Genç SZ. Öğretmen adaylarının demokratik algı ve tutumlarına yönelik tuttum ölçeği geliştirme çalışması. The Journal of Academic Social Science Studies [Internet]. 2013 Jan 1;6(7):1127-38. Available from: https://www.jasstudies.com/Makaleler/391862302_59TutkunTugay-vd-1127-1138.pdf

[18] Metin M. Kuramdan uygulamaya eğitimde bilimsel araştırma yöntemleri [From theory to practice: Scientific Research Methods in Education]. Ankara: Pegem Akademi Yayınc1lı; 2014.

[19] Turkish Statistical Institute. Women statistics, 2015 [Internet]. 2016. Available from: http://www.turkstat.gov.tr/PreHaberBultenleri.do?id=21519

[20] Aydemir H, Aksoy ND. Eğitim fakültesi öğrencilerinin demokratik tutumlarının bazı değişkenlerle ilişsisi: Malatya örneği. Erzincan Eğitim Fakültesi Dergisi. 2010;12(1):265-79.

[21] Genç SZ, Kalafat T. Öğretmen adaylarının demokratik tutumları ile empatik becerilerinin değerlendirilmesi üzerine bir araştırma. Sosyal Bilimler Dergisi [Internet]. 2008;(19):211-22. Available from: http://journals.manas.edu.kg/mjsr/oldarchives/Vol10_Issue19_2008/587-1578-1-PB.pdf 
[22] Elkatmış M, Toptaş V. Sınıf Öğretmeni Adaylarının Demokratik Tutumlarının İncelenmesi. YYÜ Eğitim Fakültesi Dergisi [Internet]. 2015;12(1):128-44. Available from: http://efdergi.yyu.edu.tr/makaleler/cilt12/iosoabdyyuefd10032014y.pdf

[23] Bulut N. Bir Grup Üniversite Öğrencisinin Demokratik Tutumları ile Çeşitli Değişkenler Arasındaki İlişkiler. Bayburt Eğitim Fakültesi Dergisi. 2006;(45):37-59.

[24] Aydoğdu F, Dilekman M. Ebeveyn tutumlarının çeşitli değişkenler açısından değerlendirilmesi. Bayburt Eğitim Fakültesi Dergisi. 2016;11(2):569-85.

\section{BIOGRAPHIES OF AUTHORS}
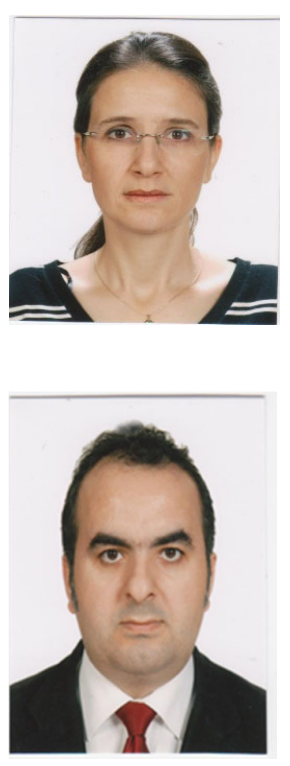

Hatice ONURAY EGILMEZ is associated proffesor in Music Education Department at Uludag University, Bursa, Turkey. She completed her Masters of Arts Degree (1998) and Doctor of Phylosophy degree (2003) in music education at Gazi University Ankara, Turkey. She teaches piano and accompanies in student concerts. She has presented papers at international conferences in Turkey, Bulgaria, Greece, Hungary, Spain and in Japan. She also written many articles in international journals. She is the Erasmus coordinator of the Music Education Department at Uludag University. In the frame of teaching staff mobility of Erasmus+ Program she also taught and gave concerts in Szeged University, Hungary (2007), in the Conservatories of Music Lorenzo Perosi (2009), Alfredo Casella (2013), Italy and Conservatorio Superior De Musica da Coruna (2017), Spain.

Özgür EGILMEZ is lecturer in Music Education Department at Uludag University, Bursa, Turkey. He completed his Masters of Arts degree in music (1998) at Gazi University Ankara, Turkey. After completing his Bachelor's degree (BA), he taught music in elementary and secondary schools for five years and worked as a violin teacher in Ankara and Bolu Anatolian Fine Arts Highschool.

Recently he is teaching violin and mandolin, Popular Music Studies, Turkish Folk Music and also supervising the teacher trainees in Music Education Department at Uludag University. He performed in various concerts in Turkey and presented papers at the conferences in Turkey, Greece, Hungary, Spain and in Japan. In the frame of Teaching Staff Mobility of Erasmus+ Program he also taught in Szeged University, Hungary (2007) and played Turkish folk songs with the "Baglama" (Turkish Folk Music instrument) at the concert held in the $12^{\text {th }}$ Cultural Festival. He also taught and gave concerts in the Conservatories of Music Lorenzo Perosi (2009), Alfredo Casella (2013), Italy and Conservatorio Superior De Musica da Coruna (2017), Spain. Now he is continuing Phd program in Mehmet Akif Ersoy University.

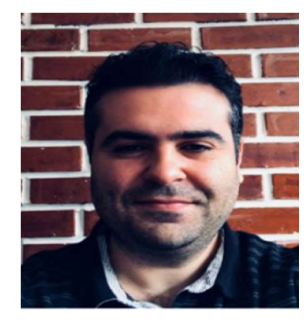

Doruk Engür is a research assistant in Music Education Department at Uludag University where he teaches courses in music theory. He has Ph.D in Music Education, MA in Music Education, MA in Assessment and Evaluation in Education, BA in Music Education and BA in Sociology. His current research interests focus on music education, music theory, assessment and evaluation, music sociology and music psychology. 